\title{
Hodnoty v opravdovém světě
}

\section{Bohuslav Binka, Jan Činčera, Martin Černý \\ Envigogika 10 (3) - Recenzované články/Reviewed articles}

Publikováno/Published dne 29. 12. 2015

DOI: $\underline{10.14712 / 18023061.505}$

\begin{abstract}
Abstrakt
Článek analyzuje možností využití Schwartzovy teorie hodnot pro programy zpracované podle modelu Real World Learning. $V$ první části představuje Schwartzovu teorii a její základní východiska. Ve druhé upozorňuje na její kritickou reflexi vyplývající z prací Pareta a Sorela. Jejím jádrem je př́lišný "optimismus" teorie, nepředpokládající schopnost hodnoty moci "maskovat" se za jiné hodnoty. Na základě této kritiky článek upozorňuje na možná rizika nereflektované snahy prosazovat ve výchově hodnoty univerzalismu a benevolence pomocí mocenského diskursu, a navrhuje jejich prevenci pomocí otevřené sebereflexe učitele.
\end{abstract}

\section{Klíčová slova} Learning

hodnoty, environmentální výchova, Schwartzova teorie hodnot, model Real World

\section{Abstract}

The paper analysis how the Schwartz' theory of universal values promoted in the Real World Learning Model might be applied in educational practice. In its first part it introduces the Schwartz' theory and its basic assumptions. In the second part it presents its critical reflection based on works of Pareto and Sorel. As they argue, the theory is too "optimistic" as it does not presuppose the ability of value of power to "mask" itself for other values. On the basis of this criticism, the paper discusses possible risks of non-reflected effort to force values of univerzalism or benevolence in education by the means of power discourse, and recommends an open self-reflection of a teacher as a prevention of such a risk.

\section{Keywords}

values, environmental education, Schwarz' theory of universal values, the Real World Learning model 


\section{Úvod}

Formování hodnot je $v$ diskursu environmentální výchovy považováno za jeden $z$ jejích přirozených cílů. Podle Tbiliské deklarace (Tbilisi Declaration, 1977) je cílem environmentální výchovy „poskytnout každému př́ležitost osvojit si (...) hodnoty (...) potřebné k ochraně a zlepšování životního prostředí. "Analogicky o formování hodnot mluví i další dokumenty, definující cíle environmentální výchovy v České republice (Pastorová a kol., 2011; Broukalová a kol., 2012). Řada autorů zkoumá vliv programů environmentální výchovy na hodnoty účastníků, přičemž zjištěná změna bývá interpretována jako úspěch programu (Schneller, Johnson, \& Bogner, 2013; Johnson \& Manoli, 2008; Manoli, Johnson, Hadjichambis, Hadjichambi, Georgiou, \& Ioannou, 2013).

Zařazení hodnot mezi cíle environmentální výchovy bývá legitimizováno několika způsoby. Výchova je vždy do určité míry hodnotově zatížená a ani environmentální výchova proto nemůže být hodnotově neutrální (Jickling, \& Spork, 1998), tj. některé hodnoty (př́roda, občanská aktivita) jsou v ní implicitně zakotveny.

Je-li v environmentální výchově jako hlavní cíl chápáno odpovědné environmentální chování (Hungerford, \& Volk, 1990), může být formování hodnot chápáno jako prostředek k jeho dosažení; vztahem mezi hodnotami a altruistickým, resp. proenvironmentálním chováním se zabývá zejména Stern (2000) či Schwartz (Schwartz, 1994; Nordlund, \& Garvill, 2002; de Groot. \& Steg, 2009), kterému bude v tomto článku věnována největší pozornost.

Konečně, vést žáky $\mathrm{k}$ přijetí určitých hodnot může být chápáno jako správné samo o sobě, bez ohledu na prípadné souvislosti s chováním.

Důraz na formování hodnot se objevuje také $v$ tzv. Modelu učení se $v$ reálném světě (Real World Learning Model, 2015a,b,c), který byl v roce 2015 publikován ve spolupráci evropských neziskových organizací a spolupracujících univerzit. Autoři modelu doporučují, aby "učitelé ve své práci rozpoznali důležitost hodnot a dbali na výběr hodnot, které bychom chtěli svou činností podporovat a rozvíjet." (Real World Learning, 2015b). Ve své argumentaci vycházejí zejména ze studií organizace Common Cause (Crompton, 2010; Blackmore et al., 2013) a Schwartzovy (1994) teorie univerzálních hodnot. Na jejich základě pak model předpokládá, že a) lidé bez ohledu na své socio-kulturní prostředí přijímají určitou sadu hodnot, které je možné rozdělit do několika kategorií, b) zatímco tzv. altruistické (self-transcended, přesažné) hodnoty, jako je univerzalismus a benevolence, podporují dlouhodobě ochotu $k$ altruistickému (včetně proenvironmentálního) chování, egoistické hodnoty (moc, úspěch) tuto tendenci oslabují, c) programy environmentální výchovy by proto měly dlouhodobě používat takové prostředky, které komunikují ${ }^{1}$ altruistické hodnoty a vyhýbají se komunikaci egoistických hodnot.

Je zřejmé, že zatímco první dva předpoklady korespondují se Schwartzovou teorií hodnot, třetí předpoklad vyjadřuje určité normativní doporučení pro praxi. Jestliže diskutu-

\footnotetext{
${ }^{1}$ Crompton (2010) a Blackmore et al. (2013), z jejichž studií model vychází, původně vztahovali Schwartzův model k analýze kampaní britských ekologických organizací, $v$ průběhu práce na modelu RWL pak došlo $\mathrm{k}$ přenosu jejich závěrů z prostředí environmentální komunikace do prostředí environmentální výchovy. Analogicky pak výchova začala být nahlížena jako určitá "komunikační situace", kdy v rámci environmentálně výchovných programů jsou „komunikována" sdělení, implicitně odkazující k určitým hodnotám.
} 
jeme o relevanci modelu RWL pro praxi outdoorové environmentální výchovy, nabízí se tedy otázka, do jaké míry je takové doporučení oprávněné.

Pro její zodpovězení se nejprve zaměříme na představení Schwartzova konceptu teorie hodnot, konkrétně pak na posouzení role, jakou Schwartz přisuzuje hodnotám v našem poznání sociální reality či $v$ rámci jednání a vztahování se ke světu, a ukážeme, jakým způsobem interpretuje vzájemné vztahy mezi hodnotami. Ve druhé části chceme upozornit na kritiku jednoho $z$ klíčových předpokladů Schwartzova modelu. $V$ poslední pak diskutujeme potenciální rizika, ale i přednosti využití modelu ve výchovně vzdělávací praxi.

Text má diskusní charakter a vyjadřuje názorovou pozici autorů.

\section{Základní východiska Schwartzovy teorie hodnot}

\section{Význam teorie hodnot v kontextu společenských věd}

Dřive než se pokusíme aplikovat Schwartzův empirický, sociálně psychologický koncept hodnot (a jeho kritiku) na oblast environmentálního vzdělávání (či specifičtěji na RWL model), podívejme se na klasifikaci př́stupů $\mathrm{k}$ teorii hodnoty $v$ rámci společenských věd. $\checkmark$ něm se, přes obrovské množství variant, vynořují tři základní odpovědi: empirickosubjektivní, normativně-objektivní a intersubjektivně-procesuální (Anzenbacher, 2001) ${ }^{2}$, ve velmi odlišné, obecnější podobě pak deskriptivní etika, preskriptivní etika a metaetika ${ }^{3}$ (Brázda, 1998). První typ odpovědi explicitně či implicitně odmítá možnost existence mimo-empirických, na lidských preferencích neodvislých hodnot a zabývá se bud' snahou o dekonstrukci všech typů normativě-objektivních př́stupư ${ }^{4}$, nebo empirickým výzkumem hodnot, tak jak jsou lidmi pocitóvány ${ }^{5}$. Druhý typ je naopak o existenci objektivních hodnot přesvědčen a snaží se různými, po většinou neempirickými metodami o jejich analýzu ${ }^{6}$. Poslední třetí typ př́stupu $\mathrm{k}$ teorii hodnot pak usiluje o určité překlenutí obou přístupů a kritizuje oběma předešlými přístupy přijímanou dichotomii norem a faktů, resp. norem a empirických danostî ${ }^{7}$. Všechny tř̌i př́stupy mají podle autorů tohoto textu určitý explorační potenciál a kombinace empiricko-subjektivního a normativně-objektivního pojetí v současném spektru výzkumu hodnot zásadním způsobem chybí (což Ize považovat za jeden z neblahých důsledků pokračující specializace vědeckého bádání). Z hlediska cílů naší studie však budeme záměrně vycházet z předpokladů, ze kterých vychází empiricko-

\footnotetext{
${ }^{2} \mathrm{~V}$ naší klasifikaci základních přístupů se $\mathrm{z}$ důvodů rozsahu této studie dopouštíme určitého zjednodušení. Z hlediska cílů, které jsme si vytkli v úvodu studie, však považujeme takové zjednodušení za obhajitelné.

${ }^{3}$ Zde naše přirovnání poněkud kulhá, protože intersubjektivně-procesuální přístupy samozřejmě neodpovídají přistupu, který reprezentuje metaetika. Na druhou stranu však (hledáme-li spojující bod) jak metaetika, tak intersubjektivně-procesuální přistupy ignorují hranice, které mezi sebou subjektivní a objektivní př́stup vybudovaly.

${ }^{4} \mathrm{~S}$ tímto př́stupem operuje například J. Derrida či W. Welsch.

${ }^{5}$ Viz např́klad námi analyzovaný S. Schwartz či P. Zimbardo a z novějších autorů např. P. Bloom či J. Haidt.

${ }^{6}$ Viz např. Spinoza, Kant, Maritain, MacIntyre.

7 Např. Dewey, Putnam.
} 
subjektivní směr hodnotového výzkumu, a ještě úžeji z chápání hodnot, jak je nacházíme př́mo u Schwartze. A to přesto, že s některými momenty kritiky empiricko-subjektivního chápání hodnot, tak jak je nalézáme u I. Kanta či A. Anzenbachera do značné míry souzníme.

Podle Schwartze představují hodnoty klíč minimálně k určité části společenskovědního poznání a bez tázání týkajícího se hodnot Ize jen obtížně vysvětlovat rozdílnosti sociálních skupin či motivaci ke změnám postojů a chování (Schwartz, 2012). Na druhou stranu byl Schwartz $v$ době formování své teorie přesvědčen i o tom, že jak současné (myšleno přibližně před rokem 1970) snahy analyzovat svět hodnot, tak dosavadní nástroje na poznávání hodnotového uspořádání jednotlivých lidí či sociálních skupin obsahují zásadní nedostatky. Analytická hodnota teorií vzniklých před Schwartzovým vystoupením je podle něho limitovaná, a to at' už se týká Rokeachovy ${ }^{8}$ (Rokeach, 1973) či SprangerovyVernorovy ${ }^{9}$ (Spranger, 1928, Allport et al., 1931) teorie. Ačkoliv totiž tyto teorie již vychází z uznání hodnot jako významného hybatele lidského jednání, zkoumají je ve velmi důležitém smyslu jako navzájem oddělené proměnné a neodhalují tak skutečnou strukturu motivů skrytých za behaviorálním chováním. Schwartz je $v$ tomto ohledu přesvědčen, že jeho teorie přináší výrazný posun právě identifikací a poznáním struktury našeho hodnotového světa jako celku.

\section{Co je to hodnota}

Podle Schwartze (2012) to, že je něco "hodnotou", znamená, že je to pro nás nějakým způsobem důležité. Jedná se o situace či stavy, jichž bychom chtěli v životě dosahovat, které nás „přitahují". Pokud je prožíváme, přináší nám to uspokojení a naplňuje nás to pocitem štěstí. $K$ hodnotám se vztahujeme $v$ závislosti na tom, jak je pro nás která $z$ nich důležitá. Každý "vyznáváme" množství hodnot (bezpečí, úspěch, otevřenost, velkorysost, ...), kterým přikládáme různou váhu. Konkrétní hodnota (úspěch) může být pro jednoho

\footnotetext{
${ }^{8}$ Podle Rokeache jsou hodnoty klíčem k tomu, o co lidé či společnost usilují. Hodnotové přesvědčení Ize pokládat nejen za kritérium hodnocení chování a jednání, ale také úsudků, postojů či argumentace. Jak uvidíme dále, Rokeach uplatňuje na hodnoty podobný přístup jako Schwartz, ovšem bez identifikace základní struktury vztahů mezi jednotlivými hodnotami. Rokeachova teorie identifikuje 18 instrumentálních a 18 terminálních hodnot. Instrumentální hodnoty se vztahují k našemu přesvědčení ohledně toho, jak by se lidé měli v životě chovat (čestnost, zodpovědnost, upřímnost...). Terminální hodnoty jsou pak přesvědčeními ohledně významu našich existencí, v jistém slova smyslu „pro co stojí za to žít": štěstí, svoboda a další. Rokeachův nástroj řadí hodnoty jednotlivců na škále podle důležitosti, kterou jim připisují. To bylo ale také často kritizováno. Podle kritiků si lidé hodnoty jednoduše "neřadí": některé hodnoty mohou být například rovnocenné nebo tak extrémně nedůležité, že prostý "žebříček" hodnot plně nereflektuje jejich skutečnou pozici. (Havlíčková, 2008).

${ }^{9}$ Spranger měl představu nadindividuálního hodnotového vědomí obsahujícího šest základních hodnot, které v různé míře podmiňuji různé formy prožívání a chování lidí. Význam každé z těchto hodnot závisí na míre, jak je upřednostňována člověkem. Těchto šest hodnotových orientací je v každém člověku zastoupeno $v$ různé proporcionalitě, přičemž jedna z nich dominuje. Spranger tyto hodnoty dále uspořádal do hierarchického hodnotového systému vzestupně v následujícím pořadí: ekonomické, teoretické, estetické, politické, sociální a náboženské, o jejichž ceně nelze podle něj pochybovat, nebot' jsou nejdůležitější pro celistvost lidstva. Toto objektivní uspořádání hodnot však může být různě př́tomno v prožívání lidí. Sprangerova teorie vychází z teze, že člověka je možno nejlépe poznat prostřednictvím studia jeho hodnot a v rámci klasifikace těchto hodnot do šesti kategorií. Tento autor pak vymezuje šest typů lidí na základě toho, jaký duchovní princip, který determinuje jejich př́stup ke světu, upřednostňují (Spranger In Smékal, 2004), a to: člověk ekonomický, teoretický, estetický, sociální, politický, náboženský (Havlíčková, 2008).
} 
člověka mimořádně důležitá, pro jiného méně a pro někoho vůbec. Pokud se člověku, pro kterého je úspěch velkou hodnotou, daři dosahovat, bude ho to pravděpodobně těšit o mnoho více než člověka, pro kterého je důležitější hodnotou např. láska či bezpečí (Schwartz, 2012).

\section{Základní vlastnosti hodnot}

Schwartzova teorie základních hodnot říká, že hodnoty $v$ sobě nesou šest vlastností. Ty jsou nepřímo zmíněny i $v$ dílech jeho předchůdců. Jedná se o následující charakteristiky (Řeháková, 2006; Havlíčková, 2008; Schwartz, 2012):

1. Význam hodnot je neoddělitelně propojený $s$ tím, jak je jimi člověk ovlivňován. Když se hodnoty "aktivuji", jsou úzce spjaty s pocity - emocemi. Lidé, pro které je nějaká hodnota důležitá, cítí emoce, mají-li pocit, že o to, co si s ní spojují, přicházejí, (např. ztráta pocitu bezpečí či neúspěch), nebo je v ohrožení (např. pocit vlastní neúspěšnosti kvůli někomu úspěšnějšímu). Stejně tak ale cítí emoce, když se naopak tato hodnota uskutečňuje (dostanu se do prostředí, které vnímám jako bezpečné). Pro koho je tedy např. nezávislost důležitou hodnotou, ten se pravděpodobně cítí ohrožený, pokud jeho osud závisí na někom jiném, bolestný pro takového člověka bude i proces, kdy o vlastní nezávislost přichází, a naopak bude štastný, pokud se bude moci sám rozhodovat, čímž bude svou nezávislost uskutečňovat.

2. Hodnoty odkazují k nějakým cílům a motivují jednání. Pro koho je právo, sociální spravedlnost či pomoc druhým významnou hodnotou, ten bude cítit motivaci k dosahování stavu, který tyto hodnoty naplňuje. Takový člověk bude zřejmě silně motivován tyto hodnoty uskutečňovat $v$ realitě, at už přímo ve svém jednání, nebo různými apely na přijetí (podle něj) žádoucích hodnot.

3. Hodnoty nejsou vázány pouze na konkrétní situace, nejsou tedy tolik podmíněny kontextem jako postoje a normy. Poslušnost a upř́mnost coby hodnoty jsou důležité nejenom ve škole, ale i v práci, při kontaktu s přáteli, nebo s cizími lidmi. Hodnoty, které jsou pro lidi důležité, se neváží jen na dané situace, jejich nositelé si je podržují při svém rozhodování a chování - to odlišuje hodnoty od norem a postojů, které jsou naopak úzce navázány na specifické okolnosti a situace.

4. Hodnoty slouží jako standardy a kritéria k poměřování dalších jevů a dějů ve světě, které kolem sebe pozorujeme. Umožňují nám zaujímat postoje k určitým politikám, lidem a událostem. S jistou nadsázkou by se dalo říci, že fungují jako jakési "majáky", které nám ř́kají, jaký by svět "měl být”; podle nich lidé poměřují odlišnosti v tom, jaký "skutečně je", či spíše, jaký se jeví. Lidé posuzují jevy či události jako "žádoucí", "nežádoucí", "správné" či "nesprávné" na základě presvědčení a pocitů spojených se svými hodnotami (resp. hodnotami, které považují za důležité). Zároveň bývá dopad hodnotových orientací na každodenní rozhodování jedince zř́dkakdy uvědomělý. Uvědomuje si jej spiše tehdy, když se rozhoduje mezi hodnotami, které jsou pro něj obě pozitivní, případně obě negativní.

5. Hodnoty mají lidé hierarchicky seřazeny podle důležitosti. Schopnost uspořádat si priority podle důležitosti zastávaných hodnot je jedním z rysů jedinečnosti každé osobnosti. Tento "vnitřní řád" (priority) také odlišuje přetrvávající hodnotové orientace od kontextuálně podmíněných postojů nebo norem chování. 
6. Relativní důležitost hodnot, resp. jejich hierarchické pořadí, vede naše jednání. Každý postoj, a následně i jednání se ovšem zpravidla váže k více než jen jedné hodnotě. Např́íklad návštěva kostela může vyjadřovat a podporovat hodnotu tradice a konformity ( $v$ prípadě, že chození do kostela je $v$ daném společenském kontextu projevem tradice a konformního chování, pochopitelně). Může ale také signalizovat zřeknutí se (tedy jakési negativní vymezení) hodnoty odpočinku a užívání si. Právě poměr, v jakém tyto navzájem se vylučující hodnoty "směňujeme", určuje výsledek - tedy naše postoje, jednání a chování. Hodnoty přitom ovlivňují jednání, pokud jsou v daném kontextu relevantní, a zároveň pokud jsou pro jednající osobu důležité (ohledně chození do kostela bude mít zřejmě malý vliv např. hodnota moci, nebot' jí v kostele Ize dosahovat pouze stěží).

Těchto šest výše popsaných charakteristik mají všechny hodnoty. Co však jednotlivé hodnoty odlišuje, je orientace motivace, kterou vyjadřují (Schwartz, 2012). Schwartzova teorie definuje hodnoty široce ve vztahu $k$ tomu, jaké motivace jsou za nimi skryté. Základní hodnoty jsou univerzální, protože se vztahují ke třem základním potřebám lidské existence, které pomáhají naplňovat. Těmito potřebami jsou zejména lidská potřeba soužití s druhými lidmi a nezbytnost zákonů, které toto soužití umožňují; a dále přežití a spokojený život lidských skupin ( $v$ posledním ohledu jde tedy nikoli o motivaci vztaženou přímo $\mathrm{k}$ jedincům, ale k nim nadřazeným sociálním celkům).

\section{Struktura hodnotového světa}

Dostáváme se tak k nejdůležitější části analýzy Schwartzovy teorie hodnot - k jeho popisu samotné struktury vztahů mezi jednotlivými základními hodnotami.

Schwartzova teorie se zabývá základními hodnotami, které jsou nějakým způsobem vnímány v každé kultuře. Nalézá celkem deset základních hodnot, které se navzájem liší svojí orientací, a upřesňuje vztahy mezi nimi. Některé základní hodnoty jsou v rozporu $\mathrm{s}$ jinými (např. benevolence a moc), zatímco jiné jsou vzájemně slučitelné (např. konformita a bezpeči). Důležité přitom podle Schwartze je, že hodnoty jsou v těchto vzájemných vztazích do značné míry nezávisle na kultuře. To znamená, že existuje určité univerzální schéma lidmi vyznávaných hodnot - a tedy i motivací lidí.

Přestože však existuje takováto univerzální interkulturní „mapa" základních hodnot, odlišuji se jednotlivé kultury (nebo skupiny uvnitř kultur) v tom, jaký důraz kladou na jednotlivé komponenty této hodnotové sktruktury.

Schwartz (2012) přitom na několika místech tvrdí, že lidé ve všech kulturách pokládají za nejdůležitější hodnoty $z$ oblasti benevolence, univerzalizmu a sebeurčení a na místa poslední hodnoty moci.

Cílem našeho textu není vymezit všechny hodnoty, které Schwartz ve svém modelu používá, je však důležité vymezit ty, jejichž porozumění je klíčové pro náš rozbor modelu RWL, tj. hodnoty benevolence, univerzalismu, sebeurčení a moci. Benevolenci Schwartz (1994) chápe jako uchování a podporu dobrého života lidí, se kterými je člověk v častém osobním kontaktu, tj. např. poctivost, přátelství či odpuštění. Univerzalismus podle něj představuje porozumění, príijetí, toleranci a ochranu dobrého života všech lidí i přírody. Př́kladem jsou sociální spravedlnost, rovnost či ochrana př́rody. Sebeurčení Schwartz chápe jako nezávislé myšlení a jednání, př́kladem je kreativita, zvědavost či svoboda. Konečně moc chápe jako sociální status a prestiž, kontrolu a dominanci nad lidmi či zdroji. Př́kladem je sociální moc, bohatství či autorita. 
Podívejme se na logiku Schwartzova konceptu, jak jí vyjadřují tři grafická zobrazení (viz obr. č. 1, 2 a 3):

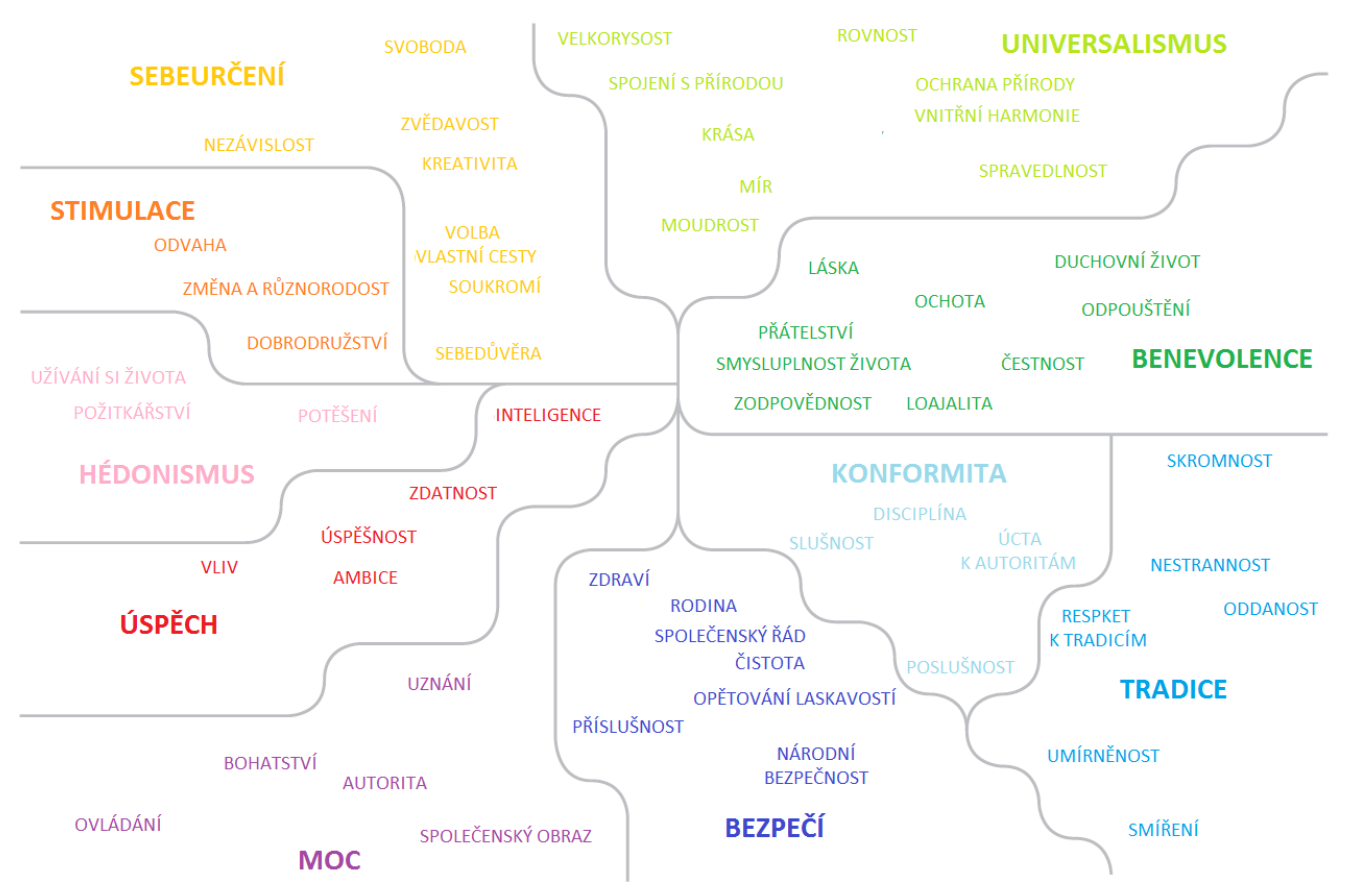

Obrázek 1: Schwartzova teorie hodnot v grafické podobě „mapy” hodnot, které se budto mohou navzájem posilovat (hodnoty zobrazené v těsné blízkosti vedle sebe), nebo se "vytlačovat" - pokud je některá hodnota zastoupena výrazně více, zmenšuje význam hodnoty umístěné v grafu naproti; ta je jí protichůdná (Schwartz, 1992). Převzato a přeloženo podle Blackmora, Sandersona a Hawkinse (2012).

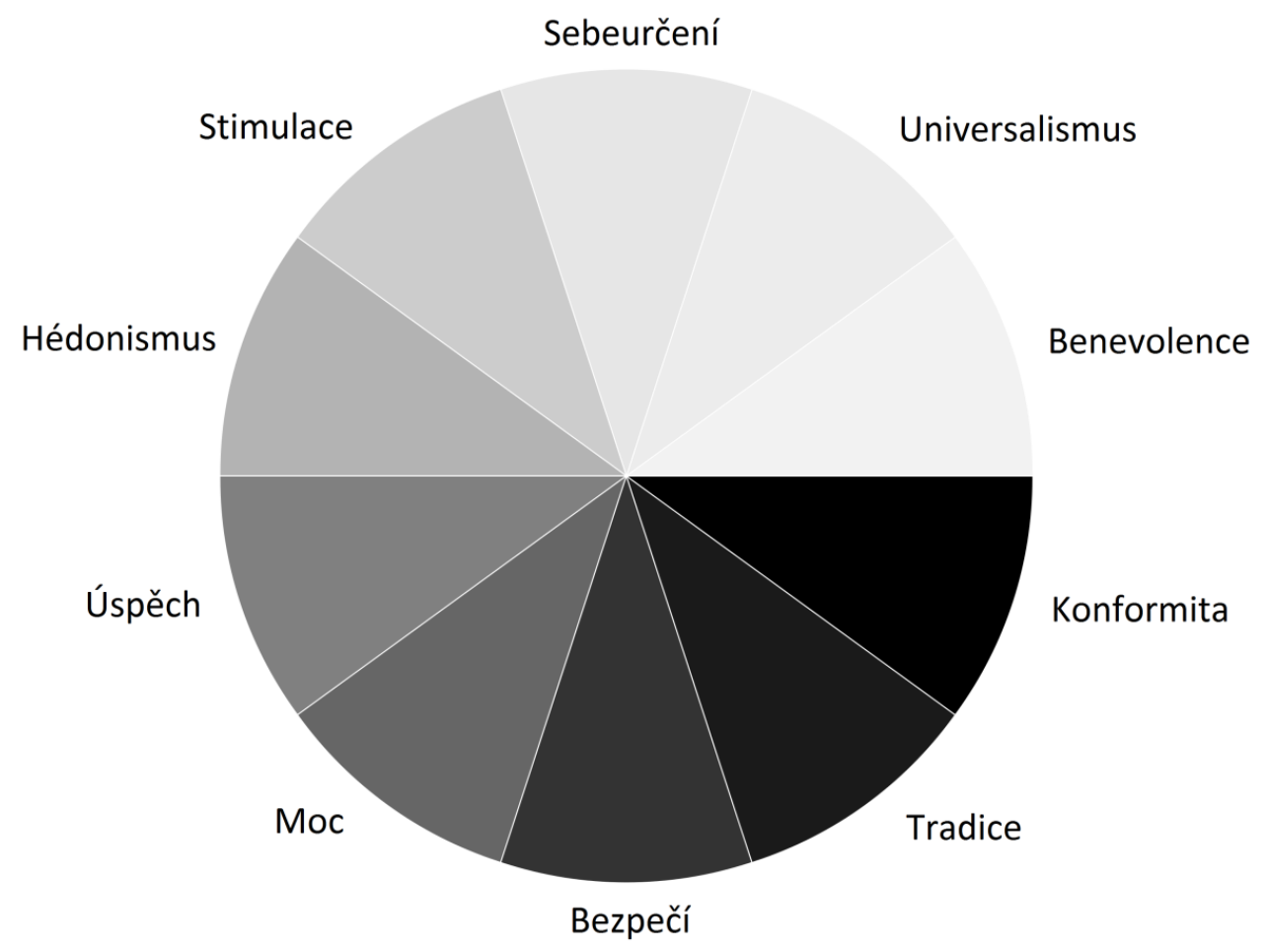




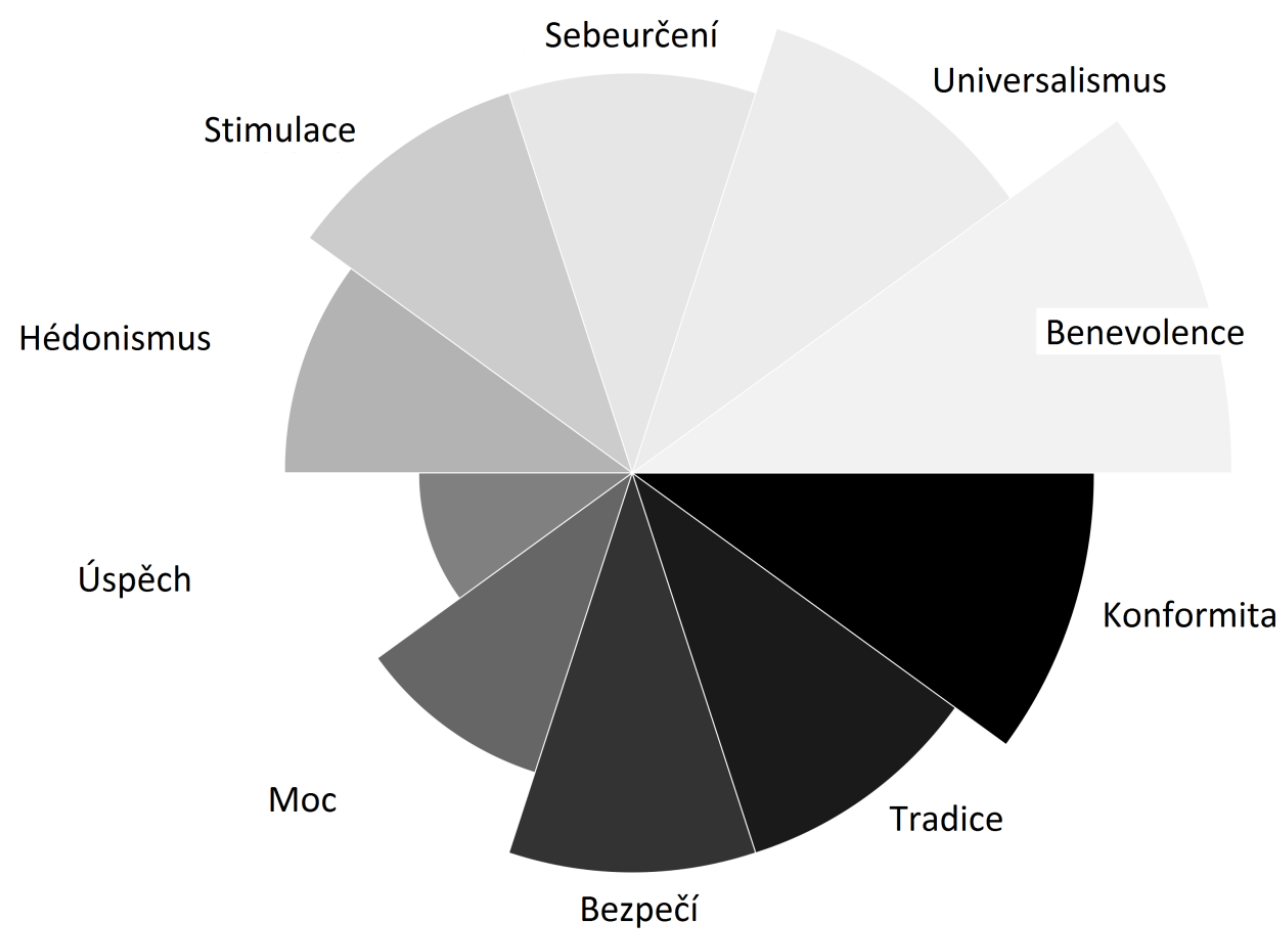

Obrázek 2 a 3: Schematicky znázorněné působení hodnot podle Schwartze. V prvním diagramu jsou všechny hodnoty zastoupeny rovnoměrně. Ve druhém př́padě jsou výrazněji zastoupeny hodnoty spojené s benevolencí. Takové „vychýlení" je podstatné i pro "sousedíci" hodnoty: konformitu a univerzalismus. Naopak, benevolence "vytlačuje" na okraj úspěch - v tomto nákresu jej spíše "vysává". Úspěch je pak jedinci díky mnohem většímu důrazu na benevolenci vnímán jako mnohem méně podstatná životní hodnota. Spolu s ním je umenšen význam moci a užívání si (hédonismu), zatímco hodnoty bezpečí, tradice, nezávislosti a stimulace zůstávají do určité míry stejné jako v prvním případě na obrázku 2. (Zdroj: původní nákresy podle Schwartzovy teorie hodnot)

Zásadní je (jak vidíme především na obrázku č. 3), že hodnoty jsou navzájem propojené a nelze je vidět jako sérii nezávislých proměnných, ale spiše jako souvislou strukturu, ve které změna jedné proměnné (neboli základní hodnoty) znamená proměnu jak hodnot sousedních, tak hodnot ležících v protikladné pozici. Ani to však není úplná interpretace hodnotového světa - obrázek č. 3 totiž nereprezentuje pouze náhodné či možné uspořádání proměn hodnot, ale vyjadřuje univerzální tendenci uspořádání hodnot. Hodnota univerzalismu a benevolence jsou totiž podle Schwartze vnímány jako zásadnější a hodnota moci jako méně významná. A to např́č kulturami a kulturními určeními.

Tento zásadní poznatek - hodnoty univerzalismu a benevolence jsou v rámci struktury našich hodnot významnější než hodnoty moci - dále potvrzoval empirický výzkum, pro který Schwartz na základě právě přiblí̌ené teorie vytvořil dva výzkumné nástroje: nejprve tzv. Schwartz Value Survey, a poté tzv. Portrait Value Questionnaire.

Právě $z$ tohoto důvodu se model RWL (Model učení se $v$ reálném světě, Real World Learning Model) na Schwartzovu teorii základních lidských hodnot a její semi-hierarchické uspořádání odvolává. Schwartzovy závěry zdá se potvrzují jistý univerzální humanismus, který je i v základech tohoto př́stupu. 


\section{Kritická reflexe Schwartzovy teorie hodnot}

Úspěch Schwartzovy teorie základních lidských hodnot (aplikace viz např. Grunert \& Juhl, 1995; Roccas, 2005; Saroglu et al., 2004; Spini, 2003; Stern et al., 2009) ve společenskovědním bádání není překvapivý. Jde o propracovanou teorii přinášející nový pohled na vzájemné provázání hodnot, která přináší robustní a přitom s teorií provázané nástroje empirického ověřování (Portrait Value Questionnaire viz Schwartz et al., 2001; Schwartz Value Survey viz Schwartz, 1992; 2003), a má význam pro praxi, což vedlo k jejímu masivnímu využití ve mnoha sférách společenskovědního empirického zkoumání (Caracciolo et al., 2015; Cohen, 2009; Ros et al., 1999; Schwartz, 2006), ale také k zajímavým teoretickým polemikám (z nedávných např́klad Datler et al., 2013; Gouveia et al., 2014; Schwartz, 2014; Paez, \& De-Juanas, 2015). A co platí pro společensky orientovaný výzkum hodnot v sociologických či psychologických disciplínách, platí i pro podmnožinu společenských věd s environmentální orientací - vliv Schwartze je zde přinejmenším významný (Grunert, \& Juhl, 1995; Lind et al., 2015; Schultz, \& Zelezny, 1998; 1999). Z tohoto pohledu se zdá být logické, že z jeho teorie vychází a využívá ji i v úvodu popsaný RWL model, který některé výsledky výzkumů založených na této teorii chápe jako vlastní předpoklady (The Real World Learning, 2015b).

A právě zde nacházíme určité problémové momenty spojení RWL modelu a Schwartzovy teorie hodnot - první souvisí s určitou problémovou částí Schwartzovy teorie základních hodnot, druhý spíše s jejím využitím v samotném RWL modelu.

Hlavním problémem, který se nachází v samotném jádru Schwartzovy teorie základních hodnot, je Schwartzem málo reflektovaný "chameleonský" charakter hodnoty moci. Na hodnotu moci jako skrývající se a částečně parazitní hodnotu upozorňují již první analytičtější přístupy v politické filosofii - Machiavelli či Hobbes a v určitém smyslu i představitelé antického myšlení (Machiavelli, 1997; 2001; Hobbes, 1965; 1969). Z našeho hlediska podstatnou analýzu však přináší především V. Pareto a jeho žák (jakkoliv politicky na jiné části spektra) G. Sorel.

Ve svém eseji „The Transformation of Democracy and the Plutocratic Cycle" se Pareto (1984) snaží dokázat, že mezi světem empirických dat a historických faktů a světem našich idejí o světě leží (částečně neproniknutelná) mlha předsudků, sentimentů, vnitřních nutkání, která nutně zkresluje naše představy o něm (Pareto, 1984). Takové zamlžení/zastření pak silně souvisí i s hodnotou moci, která se snaží - podle Pareta jde o přirozenou tendenci -běžně skrývat za hodnoty jiné (Pareto, 1984). Hodnota moci, jako skutečný hybatel jednání, se tak v naší sebeinterpretaci jeví jako hodnota sociální spravedlnosti (viz K. Marx a socialismus) ${ }^{10}$, či paradoxně hodnota svobody. Moc je - stručně řečeno - jediná hodnota, která má schopnost předstírat, že není mocí, ale celou škálou jiných hodnot.

Paretovu myšlenku podpořil a svým způsobem dále rozvinul jeho žák George Sorel (1906). Sorel ve své knize analyzuje vztah absolutního ideálu "dokonalé společnosti" a nutnosti existence vnitřního nepř́tele vysvětlujícího nevyhnutelné nedokonalosti každého společenského zřízení (včetně socialismu); v rámci této analýzy využívá Paretovo vysvětlení chameleonského charakteru moci. Socialista mocensky likvidující své bývalé soudruhy

\footnotetext{
${ }^{10}$ Pareto upozorňuje na schopnost marxistické verze socialismu skrýt hodnotu moci (která je nejsilnějším motorem marxismu) a zároveň ji cílové skupině (proletariátu) nabízet ve formě budoucího spravedlivého světa. Marx byl v tomto ohledu geniální ve schopnosti mobilizace svých souvěrců a v moralizování, za kterým je schovaná touha po moci.
} 
(publikováno v roce 1906!), protože nikdo jiný už nemůže bránit vzniku dokonalé společnosti než právě na moci se podílející soudruh, svoji činnost nevidí jako brutální využití (či zneužití) moci, ale jako uprímnou aplikaci hodnoty spravedlnosti, hodnoty stability, hodnoty „pravého života". A stejně tak reakcionář popravující socialisty nechápe své jednání jako mocenské, ale jako výraz úcty $\mathrm{k}$ hodnotě uchování společenského řádu, hodnotě tradice, hodnotě bezpečí. Stejně jako pro Pareta, ani pro Sorela neexistuje více skrytá a maskující se hodnota než hodnota moci.

Jakkoliv přesvědčivě nám mohou argumenty obou myslitelů připadat, dlouhou dobu neměly - na rozdíl od Schwartzova konceptu - přesvědčivý empirický základ. Jejich potenciál být nástrojem vhodným $\mathrm{k}$ určité kritice teorie základních hodnot neměl jinou než teoreticky-argumentační oporu.

To se však v posledních dvaceti letech výrazně mění. $Z$ jedné strany některé empirické výzkumné projekty založené na evolučním přístupu $\mathrm{k}$ společenskovědním otázkám (od Jonathana Haidta a jeho The Righteous Mind (Haidt, 2012), přes Joshua Greena a jeho Moral Tribes (Greene, 2014) či Paula Blooma s jeho Just Babies (Bloom, 2013)) a dalších behaviorálně ekonomických př́stupech (zejména Dan Ariely, ale také Michael De Lara) empiricky či semi-empiricky potvrzuji: hodnoty moci jsou nejuniverzálnějším parazitem na ostatních hodnotách, takže výzkumy, které na základě výpovědi respondentů docházejí k závěru, že moc je v porovnání s jinými hodnotami "slabším" článkem struktury hodnot, ukazují pouze nepř́mo na to, jak dobře se vnímání této hodnoty a jejího zásadního významu dokáže maskovat.

A přesně toto je př́pad Schwartzovy teorie a výsledků jeho empirických výzkumů. Je otázkou, zda Schwartzovo tvrzení prezentované v textu z roku 2012:

"Benevolence, univerzalismus a sebeurčení jsou nejdůležitějšími hodnotami. Moc a stimulace jsou nejméně důležité." (Schwartz, 2012: 14)

výrazem skutečného hodnotového nastavení respondentů, nebo spíše schopnosti hodnoty moci maskovat se za jiné hodnoty. S odkazem na Pareta, Sorela a moderní společenskovědní výzkum se spíše stavíme za druhou variantu.

\section{Aplikace Schwartzovy teorie v kontextu modelu RWL}

Přijmeme-li Paretovy a Sorelovy teze, nabízí se otázka, do jaké míry se hodnota moci může ve výchovně-vzdělávací praxi maskovat za hodnoty univerzalismu či benevolence, doporučované modelem RWL. V diskursu environmentální výchovy představuje otázka legitimity moci a hranic jejího použití pro formování postojů a hodnot dlouhodobě diskutované téma.

John Hug již v roce 1975 (cit. 1998) upozorňoval na riziko záměny role environmentálního pedagoga a aktivisty. Podle jeho názoru environmentální pedagog musí být hodnotově spravedlivý (value fair) či neutrální (value free), držet se faktů, ukazovat různé úhly pohledu a bránit se tomu, aby jeho př́padná názorová (environmentalistická) pozice ovlivnila jeho roli učitele. Hugovo doporučení ale připouští více různých interpretací a v diskursu environmentální výchovy se tak můžeme setkat $s$ širokým spektrem názorů na to, jak $\mathrm{s}$ postoji a hodnotami pracovat. $\mathrm{V}$ rámci environmentální výchovy je tak např́klad navrhováno:

- Soustředit se na fakta a na formování postojů rezignovat (Sanera, 1998); 
- vyváženě prezentovat různé postoje u témat, ke kterým neexistuje názorový konsensus (NAAEE, 2004a,b);

- nahradit „instrumentální” model environmentální výchovy, ve které rozhoduje učitel a snaží se vést žáky $k$ předem určeným cílům, výchovou nemanipulativní, demokratickou a pluralistickou, kterou řídí samotní žáci (Breiting et al., 1999; Jensen \& Schnack, 2006; Östman \& Öhman, 2007; Breiting, 2009; Wals, 2012); či naopak

- zachovat instrumentální model výchovy cíleně formující proenvironmentální postoje, hodnoty a chování jako prostředku společenské reakce na environmentální problémy (van Matre, 1990), atd.

Pluralita přístupů a složitost problematiky pak může vést $k$ tomu, že praxe environmentální výchovy překročí určitou hranici a začne uplatňovat takové postupy, ve kterých se dominantní hodnotou stane moc uplatňovaná pro formování dětí žádoucím směrem. Mocenské mechanismy, jakými jsou někdy $v$ učebnicích environmentální výchovy prosazovány správné hodnoty, přirovnali Ideland a Malmberg (2014) k nástrojům prosazování církevní moci. Žádoucí, "ekocertifikované" dítě je podle nich formováno diskursem osobní viny za globální hrozby a důležitosti oběti za "spásu" Země, "svobodného" rozhodování s předem danou "správnou" možností.

Přes jistou nadsázku si v praxi lze představit řadu variací, v jakých jsou tyto mechanismy používány: zapálené učitele, kteří ve snaze vést žáky "správným směrem" s nimi vedou zdánlivě demokratické, ale skrytě manipulované diskuse o úkolech školního ekologického klubu (Lousley, 1999; Cincera et al., 2015). Jindy se učitelé snaží distribuovat moc mezi úzkou skupinu privilegovaných žáků, kteří se pak v roli "ekohlídek" pokoušejí vynucovat učitelem dané normy mezi ostatními žáky (Cincera \& Kovacikova, 2014). V kontextu diskutované teze o "maskování" hodnoty moci za jiné hodnoty je symptomatické, že i učitelé, kteři otevřeně přiznávali manipulaci žáky, byli přesvědčení, že dělají správnou věc a jednají v nejlepším zájmu žáků i přírody (Cincera et al., 2015), stejně jako členové ekohlídek vě̌ili, že musí kontrolovat jiné děti, aby je naučily správně se chovat (Cincera \& Kovacikova, 2014).

Paradoxně pak výsledkem takové strategie nemusí být přijetí, ale negace prosazovaných hodnot, odmítání vyžadovaného a kontrolovaného chování a frustrace členů ekohlídek (Cincera \& Kovacikova, 2014). Nepřiznání si mocenského diskursu ilustruje diskutovanou vlastnost hodnoty moci maskovat se za jiné hodnoty; negace prosazovaného chování pak ukazuje nejenom etickou, ale i pragmatickou problematičnost takové strategie.

Navzdory závažnosti předkládaných argumentů je ale Sanerou (1998) prosazovaný koncept environmentální výchovy rezignující na hodnoty problematický a vnitřně rozporný. Jak uvádí Kopnina (2012), snaha o hodnotově neutrální environmentální výchovu ve skutečnosti pouze posiluje některé hodnoty oproti jiným. Environmentální tématika není ve své podstatě bez hodnotových soudů diskutovatelná: formování vztahu k přírodě implicitně předpokládá její sdílenou hodnotu, rozvoj kompetencí k zapojování se do diskusí o využívání krajiny hodnotu demokracie, analýza environmentálních konfliktů hodnotová východiska zainteresovaných stran.

Environmentální výchova je komplexní společenský projekt, ve kterém hledání hranice mezi cíleným formováním a demokratickým rozvíjením může být nejednoznačná a proměnlivá. Legitimita jednotlivých př́stupů může souviset i s hranicemi jejich aplikace: je možné, že pro formování vztahu k přírodě je instrumentální a tedy do jisté míry manipulativní (jakkoliv citlivý a motivující) př́stup zcela legitimní a vlastně přirozenou cestou, odrážející dávnou roli dospělého průvodce jako "zasvětitele", formujícího prvotní "smysl pro 
úžas" (Carson, 1965), nezbytný pro nastartování vstupního zájmu o problematiku. Stejně tak je možné, že pro rozvoj kompetencí pro řešení komplexních a nejednoznačných environmentálních dilemat je důležité, aby se učitel vzdal své moci, odolal pokušení vést studenty po "nejlepší" cestě a dopřál jim svobodu najít si svoje vlastní odpovědi.

Pokud jsme $v$ předchozí části textu upozorňovali na rizika zneužití moci při prosazování univerzalistických hodnot ve výchově, nebylo tomu tak proto, že bychom na jejich formování měli zcela rezignovat. Environmentální výchova není hodnotově neutrální (Jickling, \& Spork, 1998) a opuštění jejích hodnotových východisek by proto znamenalo vzdát se i environmentální výchovy jako takové.

Ani z Paretovy a Sorelovy analýzy nevyplývá, že by taková rezignace byla nutná, ale pouze, že práce s hodnotami je náročnější, než se může na první pohled zdát. Jestliže platí, že hodnota moci je $v$ důležitém slova smyslu chameleonská, pak je důležité rozvíjet schopnost jejího demaskování formou sebereflexe vlastních (či individuálně pocitovaných) hodnot. Proti skrývající se hodnotě moci zde nestojí jiné hodnoty (jak naznačuje Schwartzova teorie), ale samotná reflexe a ověřování všech hodnot - protože za každou může být maskovaná mocenská tendence. Uprímnost vůči sobě, ale také vưči žákům a studentům, schopnost otevřeně reflektovat hodnoty implicitně obsažené v konkrétních výchovně-vzdělávacích postupech a nezakrývat je ani před sebou, ani před žáky a studenty, by měla být prevencí nepřiznané a eticky nepřijatelné manipulace "pro dobrou věc".

V tomto smyslu netvrdíme, že sebereflexivní přístup v environmentální výchově je univerzálním či dokonalým řešením, je ale jedním z mála řešení problémů teorie moci, který máme k dispozici.

\section{Závěr}

Cílem článku bylo diskutovat potenciální rizika související s aplikací Schwartzovy teorie univerzálních hodnot obsažené v modelu RWL do pedagogické praxe. $V$ textu argumentujeme, že přestože považujeme Schwartzovu teorii za velmi užitečné východisko pro práci $\mathrm{s}$ hodnotami v programech environmentální výchovy, model RWL málo reflektuje rizika, související se specifickou schopností hodnoty moci "maskovat" se za jiné, společensky pozitivně vnímané hodnoty.

Důsledkem pak může být (vnitřně i navenek) nepřiznaný diskurs, ve kterém učitel žáky pomocí různých mocenských mechanismů manipuluje a usměrňuje i v situacích, volajících po otevřeném, demokratickém přistupu.

Prevencí takového rizika pak je sebereflexe učitele, který je schopný demaskovat skutečné hodnoty $v$ pozadí konkrétních výchovně-vzdělávacích postupů a otevřeně je přiznávat sobě i žákům.

\section{Literatura}

- Allport, G. W., Vernon, P. E., \& Lindzey, G. (1931). Study of Values: A Scale for Measuring the Dominant Interests in Personality: Test Booklet. : Houghton Mifflin.

- Blackmore, E., Underhill, R., McQuilkin, J., Leach, R., \& Holmes, T. (2013). Common Cause for Nature. Machynlleth: Public Interest Research Centre. 
- Bloom, P. (2013). Just babies: The origins of good and evil. New York: Crown.

- Broukalová, L., Broukal, V., \& Činčera, J. et al., (2012). Cíle a indikátory pro environmentální vzdělávání, výchovu a osvětu v České republice. Praha: Ministerstvo životního prostředí české republiky. Retrieved from http://www.mzp.cz/cz/cile_indikatory_evvo_dokument

- Cincera, J., \& Kovacikova, S. (2014). Being an EcoTeam Member: Movers and Fighters. Applied Environmental Education \& Communication, 13(4), 227-233. Retrieved from http://www.tandfonline.com/doi/abs/10.1080/1533015X.2015.972299 http://dx.doi.org/10.1080/1533015X.2015.972299

- Cincera, J., Kroufek, R., Simonova, P., Broukalova, L., Broukal, V., \& Skalík, J. (2015). Eco-School in kindergartens: the effects, interpretation, and implementation of a pilot program. Environmental Education Research, 1-18. Retrieved from http://www.tandfonline.com/doi/full/10.1080/13504622.2015.1076768 http://dx.doi.org/10.1080/13504622.2015.1076768

- Cohen, A. (2009). A value based perspective on commitment in the workplace: An examination of Schwartz's basic human values theory among bank employees in Israel. International Journal of Intercultural Relations, 33(4), 332-345. Retrieved from http://linkinghub.elsevier.com/retrieve/pii/S0147176709000285 http://dx.doi.org/10.1016/j.ijintrel.2009.04.001

- Datler, G., Jagodzinski, W., \& Schmidt, P. (2013). Two theories on the test bench: Internal and external validity of the theories of Ronald Inglehart and Shalom Schwartz. Social Science Research, 42(3), 906-925. Retrieved from http://linkinghub.elsevier.com/retrieve/pii/S0049089X12002591 http://dx.doi.org/10.1016/j.ssresearch.2012.12.009

- De Groot, J. I. M., \& Steg, L. (2009). Morality and Prosocial Behavior: The Role of Awareness, Responsibility, and Norms in the Norm Activation Model. The Journal of Social Psychology, 149(4), 425-449. Retrieved from http://www.tandfonline.com/doi/abs/10.3200/SOCP.149.4.425-449 pmid:19702104 http://dx.doi.org/10.3200/SOCP.149.4.425-449

- Gouveia, V. V., Milfont, T. L., \& Guerra, V. M. (2014). Functional theory of human values: Testing its content and structure hypotheses. Personality and Individual Differences, 60, 41-47. Retrieved from http://linkinghub.elsevier.com/retrieve/pii/S0191886913013895 http://dx.doi.org/10.1016/j.paid.2013.12.012

- Greene, J. (2014). Moral tribes: Emotion, reason and the gap between us and them. : Atlantic Books Ltd.

- Grunert, S. C., \& Juhl, H. J. (1995). Values, environmental attitudes, and buying of organic foods. Journal of Economic Psychology, 16(1), 39-62. Retrieved from http://linkinghub.elsevier.com/retrieve/pii/0167487094000348 http://dx.doi.org/10.1016/0167-4870(94)00034-8

- Haidt, J. (2012). The righteous mind: Why good people are divided by politics and religion. Pantheon: Vintage. 
- Havlícková, M. (2008). Hodnotové orientace současných vysokoškolských studentů a jejich vztah k jiným osobnostním a kognitivním strukturám. : 107 I., ]9] I. pril.

- Hobbes, T. (1965). O telese. Bratislava: Vydavatel'stvo Slovenskej akadémie vied.

- Hobbes, T. (1969). Leviathan, 1651. Mineola, N.Y: Scolar Press.

- Hungerford, H. R., \& Volk, T. L. (1990). Changing Learner Behavior Through Environmental Education. The Journal of Environmental Education, 21(3), 8-21. Retrieved from http://www.tandfonline.com/doi/abs/10.1080/00958964.1990.10753743 http://dx.doi.org/10.1080/00958964.1990.10753743

- Ideland, M., \& Malmberg, C. (2014). Governing 'eco-certified children' through pastoral power: critical perspectives on education for sustainable development. Environmental Education Research, 21(2), 173-182. Retrieved from http://www.tandfonline.com/doi/abs/10.1080/13504622.2013.879696 http://dx.doi.org/10.1080/13504622.2013.879696

- Jickling, B., \& Spork, H. (1998). Education for the Environment: a critique. Environmental Education Research, 4(3), 309-327. Retrieved from http://www.tandfonline.com/doi/abs/10.1080/1350462980040306 http://dx.doi.org/10.1080/1350462980040306

- Johnson, B., \& Manoli, C. C. (2008). Using Bogner and Wiseman's Model of Ecological Values to measure the impact of an earth education programme on children's environmental perceptions. Environmental Education Research, 14(2), 115-127. Retrieved from http://www.tandfonline.com/doi/abs/10.1080/13504620801951673 http://dx.doi.org/10.1080/13504620801951673

- Lind, H. B., Nordfjærn, T., Jørgensen, S. H., \& Rundmo, T. (2015). The valuebelief-norm theory, personal norms and sustainable travel mode choice in urban areas. Journal of Environmental Psychology, 44, 119-125. Retrieved from http://linkinghub.elsevier.com/retrieve/pii/S0272494415300141 http://dx.doi.org/10.1016/j.jenvp.2015.06.001

- Lousley, C. (1999). (De)Politicizing the Environment Club: environmental discourses and the culture of schooling. Environmental Education Research, 5(3), 293-304. Retrieved from http://www.tandfonline.com/doi/abs/10.1080/1350462990050304 http://dx.doi.org/10.1080/1350462990050304

- Machiavelli, N. V. (1997). Přeložil Josef Hajný. 3. vydání. Praha: Ivo Železný.Machiavelli, N. (2001). Rozpravy o prvních deseti knihách Tita Livia. Úvahy o vládnutí a vojenství, 1, 153-328.. .

- Manoli, C. C., Johnson, B., Hadjichambis, A. C., Hadjichambi, D., Georgiou, Y., \& Ioannou, H. (2014). Evaluating the impact of the Earthkeepers Earth education program on children's ecological understandings, values and attitudes, and behaviour in Cyprus. Studies in Educational Evaluation, 41, 29-37. Retrieved from http://linkinghub.elsevier.com/retrieve/pii/S0191491X13000400 http://dx.doi.org/10.1016/j.stueduc.2013.09.008 
- Nordlund, A. M., \& Garvill, J. (2002). Value Structures behind Proenvironmental Behavior. Environment and Behavior, 34(6), 740-756. Retrieved from http://eab.sagepub.com/cgi/doi/10.1177/001391602237244 http://dx.doi.org/10.1177/001391602237244

- Paez, J., \& De-Juanas, A. (2015). Validation of "Schwartz Values Scale" for Spanish Adolescents Population. Procedia - Social and Behavioral Sciences, 165, 195-201. Retrieved from http://linkinghub.elsevier.com/retrieve/pii/S1877042814067615 http://dx.doi.org/10.1016/j.sbspro.2014.12.622

- Pareto, V. (1984). The transformation of democracy. : Transaction Publishers.

- Pastorová, M., \& et al., (2011). Doporučené očekávané výstupy. Metodická podpora pro výuku průřezových témat na základních školách. Praha: Výzkumný ústav pedagogický. Retrieved from http://www.vuppraha.cz/nova-publikace-divize-vup\%E2\%80\%93-doporucene-ocekavane-vystupy-pro-zakladni-skoly

- Roccas, S. (2005). Religion and Value Systems. J Social Issues, 61(4), 747-759. Retrieved from http://doi.wiley.com/10.1111/j.1540-4560.2005.00430.x http://dx.doi.org/10.1111/j.1540-4560.2005.00430.x

- Saroglou, V., Delpierre, V., \& Dernelle, R. (2004). Values and religiosity: a metaanalysis of studies using Schwartz's model. Personality and Individual Differences, 37(4), 721-734. Retrieved from http://linkinghub.elsevier.com/retrieve/pii/S0191886903004033 http://dx.doi.org/10.1016/j.paid.2003.10.005

- Rokeach, M. (1973). The nature of human values. New York: Free press.

- Ros, M., Schwartz, S. H., \& Surkiss, S. (1999). Basic individual values, work values, and the meaning of work. Applied psychology, 49-71.

- Řeháková, B. (2006). Měření hodnotových orientací metodou hodnotových portrétů SH Schwartze. Sociologický časopis/Czech Sociological Review, 01, 107-128.

- Schneller, A. J., Johnson, B., \& Bogner, F. X. (2013). Measuring children's environmental attitudes and values in northwest Mexico: validating a modified version of measures to test the Model of Ecological Values (2-MEV. Environmental Education Research, 21(1), 61-75. Retrieved from http://www.tandfonline.com/doi/abs/10.1080/13504622.2013.843648 http://dx.doi.org/10.1080/13504622.2013.843648

- Schultz, P. W., \& Zelezny, L. C. (1998). Values and Proenvironmental Behavior: A Five-Country Survey. Journal of Cross-Cultural Psychology, 29(4), 540-558. Retrieved from http://jcc.sagepub.com/cgi/doi/10.1177/0022022198294003 http://dx.doi.org/10.1177/0022022198294003

- Schultz, P. W., \& Zelezny, L. (1999). Values as predictors of environmental attitudes: Evidence for consistency across 14 countries. Journal of environmental psychology, 19(3), 255-265.

- Schwartz, S. H. (1992). Universals in the content and structure of values: Theoretical advances and empirical tests in 20 countries. Advances in experimental social psychology, 25(1), 1-65. 
- Schwartz, S. H. (1994). Are There Universal Aspects in the Structure and Contents of Human Values. Journal of Social Issues, 50(4), 19-45. Retrieved from http://doi.wiley.com/10.1111/j.1540-4560.1994.tb01196.x http://dx.doi.org/10.1111/j.1540-4560.1994.tb01196.x

- Schwartz, S. H., Melech, G., Lehmann, A., Burgess, S., Harris, M., \& Owens, V. (2001). Extending the Cross-Cultural Validity of the Theory of Basic Human Values with a Different Method of Measurement. Journal of Cross-Cultural Psycholo$g y, 32(5), 519-542$. Retrieved from http://jcc.sagepub.com/cgi/doi/10.1177/0022022101032005001 http://dx.doi.org/10.1177/0022022101032005001

- Schwartz, S. H. (2003). A proposal for measuring value orientations across nations. Questionnaire Package of the European Social Survey. , 259-290.

- Schwartz, S. H. (2006). Basic human values: Theory, measurement, and applications. Revue française de sociologie, 47(4), 249-288.

- Schwartz, S. H. (2012). An Overview of the Schwartz Theory of Basic Values An Overview of the Schwartz Theory of Basic Values, 2, 1-20. .

- Schwartz, S. H. (2014). Functional theories of human values: Comment on Gouveia, Milfont, and Guerra (2014. Personality and Individual Differences, 68, 247249. Retrieved from http://linkinghub.elsevier.com/retrieve/pii/S0191886914001834 http://dx.doi.org/10.1016/j.paid.2014.03.024

- Sorel, G. (1906). Reflections on Violence. TE Hulme. London: Collier.

- Spini, D. (2003). Measurement equivalence of 10 value types from the Schwartz Value Survey across 21 countries. Journal of cross-cultural psychology, 34(1), 323. Retrieved from http://jcc.sagepub.com/cgi/doi/10.1177/0022022102239152 http://dx.doi.org/10.1177/0022022102239152

- Stern, P. C. (2000). New Environmental Theories: Toward a Coherent Theory of Environmentally Significant Behavior. J Social Isssues, 56(3), 407-424. Retrieved from http://doi.wiley.com/10.1111/0022-4537.00175 http://dx.doi.org/10.1111/0022-4537.00175

- Stern, P. C., Dietz, T., Abel, T. D., Guagnano, G. A., \& Kalof, L. (1999). A valuebelief-norm theory of support for social movements: The case of environmentalism. Human ecology review, 6(2), 81.

- Tbilisi Declaration (1977). Tbilisi Declaration. . Retrieved from http://www.gdrc.org/uem/ee/tbilisi.html

- The Real World Learning (2015) Real world learning model. Retrieved from http://www.rwlnetwork.org/rwl-model.aspx

- The Real World Learning (2015) Values. Retrieved from http://www.rwlnetwork.org/rwl-model/values.aspx

- The Real World Learning (2015) Are self-transcendence values promoted?. Retrieved from http://www.rwlnetwork.org/media/75963/values - full text.pdf 
- Van Matre, S. (1990). Earth education ... a new beginning. Greenville: Institute for Earth education.

- Wals, A. (2012) Learning our way out of unsustainability: the role of environmental education. In S. Clayton (Ed.), The Oxford Handbook of Environment and Conservation (pp. 628-644). Oxford: Oxford university press.

- Wals, A. E. J., Geerling-Eijff, F., Hubeek, F., van der Kroon, S., \& Vader, J. (2008). All Mixed Up? Instrumental and Emancipatory Learning Toward a More Sustainable World: Considerations for EE Policymakers. Applied Environmental Education \& Communication, 7(3), 55-65. Retrieved from http://www.tandfonline.com/doi/abs/10.1080/15330150802473027 http://dx.doi.org/10.1080/15330150802473027 